\title{
SANKSI KERJA SOSIAL, SEBUAH ALTERNATIF PENALISASI TERHADAP PELANGGARAN LALU LINTAS DI KOTA PAREPARE
}

\author{
Firmansyah, Wahyu Rasyid \\ Fakultas Hukum \\ Universitas Muhammadiyah Parepare,Jalan Jenderal Ahmad Yani KM 6 Kota Parepare kode \\ Pos 91113, Telepon: 0421-22757/Fax 0421-2554 Sulawesi Selatan Indonesia \\ Email: firmansyah.abdurrahman85@gmail.com
}

\begin{abstract}
Social work sanctions is an alternative in handling traffic violations without going through a litigation process, this research aims; First, to find out the right strategies related to social work sanctions. Second, to find out the factors that influence the implementation of social work sanctions and finally to find out the impact of the application of social work sanctions. The research method used is a socio-normative research method. Data collection techniques for library research and interviews. The results of this study indicate that the strategies is used in implementing social work sanctions are; Field survey, socialization Collaborate with the police to conduct sweeping on the object of research, carry out social / social work sanctions and install stickers to control and there needs to be a conscious area or traffic order. namely the existence of the concept of ultimum Remedium. It's mean that criminal is the last step and the Discretion is a power or authority that is carried out based on the law for consideration and belief and emphasizes moral considerations rather than legal considerations. The inhibiting factors are; Written rules or regulations / substances that do not yet exist, lack of socialization and legal culture or attitudes of both the community and the police are still low regarding legal issues. Finally, the impact of the implementation is the creation of rules or laws that specifically regulate the issue of social work sanctions. The next thing is the creation of the Community Police Concept.
\end{abstract}

Keyword: social work sanctions, substance, culture, discretion

\begin{abstract}
Abstrak :Sanksi kerja social merupakan sebuah alternative dalam penanganan pelanggaran lalu lintas tanpa melalui proses litigasi, penelitian ini bertujuan; pertama, Untuk mengetahui strategi-strategi yang tepat terkait dengan sanksi kerja sosial. Kedua, untuk mengetahui faktor-faktor yang mempengaruhi penerapan sanksi kerja sosial dan terakhir untuk mengetahui dampak dari penerapan sanksi kerja sosial. Metode penelitian yang digunakan adalah metode penelitian sosio-normatif. Teknik pengambilan data studi kepustakaan dan wawancara. Hasil penelitian ini menunjukkan bahwa langkah atau strategi yang di gunakan dalam penerapan sanksi kerja social yaitu; Survey lapangan, Sosialisasi Berkerjasama dengan polisi untuk melakukan sweeping terhadap objek penelitian, Melaksanakan sanksi kerja social/Bakti social dan Melakukan pemasangan stiker untuk melakukan control dan perlu ada daerah sadar lalu lntas atau kawasan tertib lalu lintas.faktor pendukung penerapan sanksi kerja social yaitu Secara substansi yakni adanya konsep ultimum Remedium atau sarana pidana sebagai langkah terakhir dan Diskresi adalah suatu kekuasaan atau wewenang yang dilakukan berdasarkan hukum atas pertimbangan dan keyakinan serta lebih menekankan pertimbangan-pertimbangan moral dari pada pertimbangan hukum. Adapun factor penghambat yaitu; Aturan atau regulasi/substansi secara tertulis yang belum ada, Sosialisasi yang kurang dan Culture
\end{abstract}


Hukum atau sikap baik masyarakat maupun polisi yang masih rendah terkait masalah Hukum. Terakhir dampak penerapannya adalah akan terciptanya aturan atau Undang-undang yang khusus mengatur masalah sanksi kerja social. Hal selanjutnya adalah terciptanya Konsep Polisi Masyarakat (Polmas).

Kata kunci: sanksi kerja social, substansi, culture, diskresi

\section{LATAR BELAKANG}

Hukum selalu melekat pada kehidupan manusia sebagai induvidu atau pun masyarakat, senada dengan itu, oleh Cicero dikatakan bahwa " $u b i$ societes $u b i$ ius" dimana ada masyarakat disitu ada hukum, sesuai dengan pernyataan tersebut, hukum selalu hadir ketika ada masyarakat, dimana hukum berfungsi menertibkan dan mengatur pergaulan dalam masyarakat serta menyelesaikan masalah-masalah yang timbul dalam kehidupan masyarakat, di sini hukum berfungsi sebagai norma untuk mengatur relasi antar anggota masyarakat, sehingga membuat mereka terikat dengan kewajiban dan tanggungjawab hukum (legal responsibility), hal itu sebagai konsekuensi bahwa eksistensi manusia adalah koeksistensi, dimana manusia tidak dapat hidup tanpa orang lain dengan hak, kewajiban dan tuntutan yang berbeda-beda dan hal itu adalah kenyataan eksistensial.

Adapun pembagian Hukum, salah satunya adalah Hukum Pidana yang oleh Van Hammel adalah:

"suatu keseluruhan dari asas-asas dan aturan-aturan yang ditaati negara atau masyarakat hukum umum lainnya yang mana mereka adalah pemelihara ketertiban hukum umum telah melarang perbuatan-perbuatan yang bersifat melanggar hukum dan telah mengaitkan pelanggaran terhadap aturan-aturan dengan suatu penderitaan yang bersifat khusus berupa pidana",.

Sedangkan menurut Moeljatno bahwa hukum pidana adalah:

"bagian dari keseluruhan hukum yang berlaku disuatu negara, yang mengadakan dasar-dasar dan aturan-aturan untuk, pertama, menetukan perbuatan-perbuatan mana yang tidak boleh dilakukan, yang dilarang dengan disertai ancaman atau sanksi yang berupa pidana tertentu bagi barang siapa melanggar larangan tersebut. kedua, menentukan kapan dan dalam hal-hal apa kepada mereka yang telah melanggar laranganlarangan itu dapat dikenakan atau dijatuhi pidana sebagaimana telah

\footnotetext{
${ }^{1}$ Eddy OS Hiariej, Prinsip-prinsip Hukum Pidana, (Yogyakarta:Cahaya Atma Pustaka, 2014), hlm 12
} 
diancamkan. Dan yang ketiga, menentukan dengan cara bagaimana pengenaan pidana itu dapat dilaksanakan apabila ada orang yang disangka telah melanggar larangan tersebut ${ }^{2}$."

Dari pandangan tersebut dapat ditarik sebuah kesimpulan bahwa tiga elemen yang penting dalam hukum pidana yaitu perbuatan pidana, pertanggungjawaban pidana dan yang terakhir adalah pidana atau penalisasi, salahsatu masalah yang berkaitan dengan pidana atau penalisasi adalah penentuan sanksi pidana terhadap perbuatan yang dilanggar $^{3}$ dalam penentuan sanksi para pembuat kebijakan harus berhati-hati karena hal tersebut berkaitan dengan masalah Hak Asasi Manusia, olehnya itu seyogyanya Hukum pidana itu sebagai langkah terakhir (ultimum Remedium). Terkait dengan masalah sanksi, maka lahir konsep double track system ${ }^{4}$ yakni sanksi pidana dan sanksi tindakan, salahsatu bentuk dari sanksi tindakan adalah pembinaan (pidana kerja sosial) dalam konteks ini penulis mengusulkan sanksi

\footnotetext{
${ }^{2}$ Moeljanto, Asas-Asas Hukum Pidana, (Jakarta:Pt. Rineka Cipta, 2008), hlm 1

${ }^{3}$ Teguh Prasetyo,politik Hukum Pidana, hlm 82

${ }^{4}$ Sholehuddin, Sistem Sanksi dalam Hukum

Pidana,ide dasar double track system \&

implementasinya, cetakan kedua (Jakarta:PT

RajaGrafindo Persada, 2004), hlm 23
}

kerja sosial yang terinspirasi dari konsep pidana kerja sosial.

Filosofi pidana kerja sosial ini merujuk pada pancasila yang memuat nilai-nilai, seperti nilai Ketuhanan, kemanusian, persatuan, musyawarah/demokrasi, serta nilai-nilai keadilan, hal ini semua yang harus menjadi landasan dalam penetapan kerja sosial sebagai alternatif pemidanaa. Pidana kerja sosial selaras dengan sila kelima pancasila yaitu keadilan sisoal bagi seluruh rakyat Indonesia yang didalamnya terkandung nilai kerja keras yang merupakan sarana untuk menuju keadilan sosial, selain itu juga sesuai dengan sila ke-2 dimana terkandung nilai-nilai pengakuan terhadap martabat manusia, dimana manusia dituntut berlaku adil dan menghormati hak asasi manusia lainnya dan hal ini tampak dari terpidana yang ditempatkan di tempat kerja sesuai dengan keterampilan dan bakat narapidana, tidak merampas kemerdekaan narapidana dan dibimbing ke jalan yang lebih benar oleh petugas yang berkompoten. $^{5}$

Selain landasan filosofi diatas, secara teoritis pidana kerja sosial juga sesuai dengan tujuan pemidanaan yang integratif yakni memberikan perlindungan

\footnotetext{
${ }^{5}$ Widodo, sistem pemidanaan dalam cyber crime, cetakan pertama (Yogyakarta:Laksbang Mediatama, 2009), hlm183
} 
terhadap masyarakat, dimana penjatuhan pidana kerja sosial, masyarakat terlindungi dari pengulangan tindak pidana, sebagai pemelihara solidaritas masyarakat, dimana melalui kerja sosial masyarakat mengetahui bahwa terpidana sudah dijatuhi hukuman sehingga memperkecil atau bahkan meniadakan kemungkinan balas dendam $^{6}$ selain itu para terpidana juga dapat terhindar dari perampasan kemerdekaan serta stigmatisasi.

Hal yang menjadi perhatian dalam pidana kerja sosial adalah persoalan gradasi, dimana pidana sosial hanya dapat diterapkan terhadap tindak pidana yang tidak terlalu berat atau dengan kata lain tidak dijatuhkan untuk tindak pidana yang berat, untuk konteks Indonesia berdasarkan ketentuan pasal 52 KUHP majelis Hakim sepakat untuk pidana kerja sosial diberlakukan terhadap terpidana yang tidak melebihi 6 bulan, selain itu berkaiatan juga dengan usia pelaku, misalnya di bawah umur tidak dikenakan pidana kerja sosial, dan juga harus diperhatikan jam kerja, berkaitan dengan ketentuan minimum pidana kerja sosial dibebarapa negara terdapat perbedaan, di Portugal dilakukan dalam waktu 9 jam, di Denmark, Prancis, Inggris minimum $40 \mathrm{jam}^{7}{ }^{\text {Untuk konteks }}$ Indonesia sesuai Undang-Undang

\footnotetext{
${ }^{6}$ Ibid, hlm 190

${ }^{7}$ Ibid, hlm 11
}

Ketenagakerjaan maka batas minimun adalah 8 jam kerja, olehnya itu terkait dengan pidana kerja sosial ini sudah seharusnya diakomodasi dalam Undangundang sebagai alternatif pemidanaan.

Sanksi kerja sosial yang penulis tawarkan khususnya dalam konteks kota pare-pare Sulawesi-Selatan berkaitan dengan kondisi riel terkait pelanggaran lalu lintas yang terjadi dimana pada saat operasi Zebra yang diadakan selama 14 hari di penghujung tahun 2016 terdapat 379 pelanggaran lalu lintas, dengan rincian 348 surat tilang yang dikeluarkan dan 30 teguran. ${ }^{8}$ Dari data tersebut dapat dianalisis bahwa terjadi pelanggaran lalu lintas di kota Pare-pare selama 1 hari sebesar 27 pelanggaran, untuk meminimalisir maka tawaran penulis adalah pengenaan sanksi kerja sosial

Penerapan sanksi kerja sosial untuk para pelanggar lalu lintas ini dikemas dalam bentuk bakti sosial kapada masyarakat-masyarakat miskin di kota Pare-pare, sesuai data yang dilansir oleh Badan Pusat Statistik (BPS) dipenghujung tahun 2016 bahwa kehidupan warga miskin di kota Pare-pare sangat memprihatinkan, dimana pada tahun 2015 warga yang

\footnotetext{
${ }^{8}$ http://news.rakyatku.com/read/6981/2016/05/30/3 23-pelanggar-lalu-lintas-dibukukan-polresparepare, diakses tanggal 9 Mei 2017
} 
berada di bawah garis kemiskinan mencapai 8400 orang dari 138 ribu jumlah penduduk mengalami kenaikan dari tahun sebelumnya dari 8100 orang dari 137 ribu penduduk ${ }^{9}$ dari data tersebut terlihat kuantitas warga miskin di Parepare cukup memprihatinkan, olehnya itu pengenaan sanksi kerja sosial (bakti sosial) sebagai alternative dengan argumentasi baik secara filosofis, yuridis dan sosiologis, dimana secara filosofi akan terlahir nilai-nilai untuk saling berbagi terhadap sesama, selain itu hakikat dari Hukum pidana sesungguhnya adalah Ultimum remedium atau hukum pidana itu adalah langkah terakhir, kalau masih bisa diselesaikan secara non-penal, sebaiknya tidak usah dilanjutkan dalam proses hukum.

Kedua, secara yuridis berdasarkan ketentuan pasal 52 KUHP majelis Hakim sepakat untuk pidana kerja sosial diberlakukan terhada terpidana yang tidak melebihi 6 bulan penjara, selain itu juga terkait dengan kewenangan diskresi yang dimiliki oleh pihak kepolisian yaitu suatu kewenangan yang bersumber dari asas kewajiban umum kepolisian (plechmatigheid beginsel) yaitu asas yang memberikan kewenangan kepada Polisi untuk bertindak atau tidak bertindak

${ }^{9}$ http://lintasterkini.com/03/11/2016/data-bpswarga-miskin-kota-parepare-capai-8-400orang.html, diakses tanggal 18 Juni 2017 menurut penilaiannya sendiri dalam rangka kewajiban umum menjaga, memelihara ketertiban dan menjaga keamanan umum, hal ini didasari pada pasal 18 Undangundang No.2 tahun 2002 tentang Kepolisian Republik Indonesia yaitu "untuk kepentingan umum, pejabat Kepolisian negara Republik Indonesia dalam melaksanakan tugas dan wewenangnya dapat bertindak menurut penilaianya sendiri" untuk mengambil kebijakan strategis berkaitan dengan pelanggaran Lalu lintas.

Ketiga, secara sosiologis berkaitan dengan perbaikan budaya Hukum baik secara Internal di kepolisian dan sebagai tindak lanjut dari konsep Polisi Masyarakat yang mempunyai tujuan yaitu menurunkan rasa takut dikalangan warga, meningkatkan kepuasan warga terhadap polisi dan pengembangan teknik-teknik untuk mengatasi masalah-masalah masyarakat. Dan mempunyai prinsif yaitu membangun komunitas (Community building), kepercayaan (Trust), dan kerjasama ${ }^{10}$.Secara eksternal mampu memperbaiki budaya hukum para pelanggar Lalu lintas secara khusus dan masyarakat secara umum, serta pidana kerja sosial bisa menekan angka

\footnotetext{
${ }^{10}$ Sutanto, hermawan et.al., Polmas falsafah baru Pemolisian, cetakan kedua (Jakarta:Pensil-324, 2008), hlm 10-11
} 
kemiskinan dan ajang silaturrahmi antar polisi dengan masyarakat atau dengan para pelanggar lalu lintas.

Selain alasan-alasan tersebut, menurut pengamatan peneliti, belum pernah ada yang melakukan penelitian yang sama dengan judul penelitian ini, ada beberapa alasan karena secara yuridis pidana kerja sosial belum diakomodasi dalam Kitab Undang-undang Hukum Pidana (KUHP) dan Pidana kerja sosial masih belum populer, olehnya itu melalui penelitian ini diharapkan pidana kerja sosial bisa diakomodasi dalam Kitab Undang-undang Hukum Pidana (KUHP). Berdasarkan argumen diatas maka peneliti akan menganalisis seperti apa strategi yang tepat dalam penerapan sanksi kerja sosial dan faktor-faktor yang mempengaruhi dalam penerapan sanksi kerja sosial, serta dampak sanksi kerja sosial. Adapun rumusan masalah dalam tulisan ini adalah pertama, Bagaimana strategi penerapan sanksi kerja sosial terhadap para pelanggar lalu lintas di kota Parepare. Kedua, Apa Faktor-faktor yang mempengaruhi penerapan sanksi kerja sosial di kota Parepare dan terakhir Bagaimana dampak penerapan sanksi kerja sosial terhadap para pelaggar lalu lintas di kota Parepare.

\section{METODE PENULISAN}

\section{Tipe Penelitian}

Dalam penelitian ini penulis menggunakan jenis penelitian Hukum sosio-normatif yang terdiri atas penelitian normatif dan sosiologis, dimana penelitian penelitian hukum normatif yaitu penelitian untuk menemukan inconcreto (kenyataan hukum ) yang meliputi berbagai kegiatan untuk menemukan apakah yang merupakan hukum yang layak untuk diterapkan secara inconcreto untuk menyelesaikan suatu perkara tertentu. Dalam kaitanya dengan penelitian normatif disini digunakan pendekatan perundang-Undangan (statue approach) untuk mengkaji beberapa Undang-undang terkait dengan masalah pidana kerja sosial, serta masalah lalu lintas, adapun beberapa Undang-undang yang dikaji adalah Kitab Undang-undang Hukum Pidana, Undang-undang Kepolisian serta Undang-undang lalu lintas.

Tipe penelitian yang kedua adalah pendekatan sosiologis, yaitu suatu prosedur penelitian ilmiah untuk menemukan kebenaran yang tidak hanya berdasarkan logika keilmuan hukum dari sisi norma saja, tetapi hukum yang pada kenyataaanya terjadi di masyarakat dalam hal ini yang penulis maksud adalahbudaya Hukum internal yakni budaya Hukum Kepolisian dan budaya Hukum eksternal dalam hal ini adalah budaya Hukum pelanggar Lalu lintas secara khusus dan masyarakat secara 
umum, serta penerapan sanksi kerja sosial kepada para pelanggar lalu lintas beserta dampaknya baik bagi kepolisian, pelanggar lalu lintas dan masyarakat.Rancangan Penelitian ini mengkaji tentang penerapan Sasi kerja Sosial terhadap pelanggaran lalu lintas di kota Parepare.

\section{Teknik Pengumpulan Data}

Penelitian ini menggunakan Data primer dan data sekunder. Data primer merupakan bahan penelitian yang berupa fakta-fakta empiris sebagai perilaku maupun hasil perilaku manusia yang diperoleh secara langsung dari sumber pertama (asli) pada lokasi penelitian yakni terkait dengan budaya hukum baik pihak kepolisian maupun para pelanggar lalu lintas di kota Pare-pare dengan menggunakan metode wawancara baik kepada pihak kepolisian, para pelanggar lalu lintas maupun masyarakat secara umum, disamping itu penulis juga melakukan observasi, dan selanjutnya menggunakan data sekunder yang merupakan jenis bahan yang didapat bukan dari lapangan dan didapat dalam bentuk dua bahan hukum dan satu bahan tersier, yaitu: pertama, Bahan hukum primer, yaitu bahan-bahan hukum formal, yakni Undang-Undang Nomor 2 Tahun 2002 tentang kepolisian, Kitab Undang-Undang Hukum Pidana,Undang-Undang No.22 Tahun 2009 tentang Lalu lintas dan angkutan jalan serta beberapa UndangUndang terkait. Kedua, Bahan hukum sekunder, yaitu bahan hukum terdiri atas buku-buku teks yang ditulis para ahli hukum yang berpengaruh, jurnal-jurnal hukum, pendapat para sarjana yang berkaitan dengan topik penelitian. Dan terakhir Bahan hukum tersier, yaitu bahan hukum yang memberi petunjuk maupun penjelasan terhadap bahan hukum primer dan bahan hukum sekunder, seperti kamus dan lain-lain.

\section{Teknik Analisis Data}

Dalam menganalisis data dilakukan secara deskriptif dengan pendekatan kualitatif, bahwa data yang dinyatakan oleh responden secara tertulis atau lisan serta juga tingkah laku yang nyata, setelah melakukan tabulasi kemudian dianalisis dengan menggunakan beberapa teori sebagai pisau analisis serta menjawab permasalahan yang diangkat sehingga memperoleh gambaran atau pemaparan yang lengkap dan mendalam (verstehen) tentang strategi-strategi yang tepat dalam penerapan sanksi kerja sosial serta faktorfaktor yang mempengaruhi penerapan sanksi kerja sosial, Kemudian sebagai langkah terakhir ditarik kesimpulan dengan menggunakan metode induktif sebagai pegangan utama berdasarkan fakta-fakta yang terjadi, sehingga didapat sebuah 
generalisasi terkait dengan efektivitas sanksi kerja sosial serta gambaran budaya hukum kepolisian, para pelanggar Hukum serta masyarakat setelah penerapan sanksi kerja sosial.

\section{PEMBAHASAN}

\section{Strategi Penerapan Sanksi kerja} sosial terhadap Pelanggaran Lalu Lintas Di kota Parepare

Sanksi kerja social merupakan inspirasi dari Pidana kerja social yang diterapkan dibeberapa negara, dimana dalam konteks Indonesia Filosofi pidana kerja sosial ini merujuk pada pancasila yang memuat nilai-nilai, seperti nilai Ketuhanan, kemanusian, persatuan, musyawarah/demokrasi, serta nilai-nilai keadilan, hal ini semua yang harus menjadi landasan dalam penetapan kerja sosial sebagai alternatif pemidanaa. Pidana kerja sosial selaras dengan sila kelima pancasila yaitu keadilan sisoal bagi seluruh rakyat Indonesia yang didalamnya terkandung nilai kerja keras yang merupakan sarana untuk menuju keadilan sosial, selain itu juga sesuai dengan sila ke-2 dimana terkandung nilai-nilai pengakuan terhadap martabat manusia, dimana manusia dituntut berlaku adil dan menghormati hak asasi manusia lainnya dan hal ini tampak dari terpidana yang ditempatkan di tempat kerja sesuai dengan keterampilan dan bakat narapidana, tidak merampas kemerdekaan narapidana dan dibimbing ke jalan yang lebih benar oleh petugas yang berkompoten.

Penerapan saksi kerja social merupakan pengejawantahan dari konsep double track system yang berorientasi pada pelaku dan perbuatan (daad-daader straafrecht), jenis sanksi yang ditetapkan tidak hanya meliputi sanksi pidana, tetapi juga sanksi tindakan, dimana sistem dua jalur ini menempatkan kedua jenis sanksi ini dalam keadaan setara, kedua sanksi ini mempunyai landasan filsafat yang memayunginya yaitu, Filsafat indeterminisme sebagai landasan sanksi pidana, bahwa sejatinya manusia memiliki kehendak bebas, termasuk ketika dia melakukan kejahatan, sebagai konsekuensi pilihan bebasnya maka setiap pemidanaan harus diarahkan pada pencelaan moral dan pengenaan penderitaan bagi pelaku dan sebagai landasan teorinya adalah teori absolut yang memandang bahwa pemidanaan sebagai pembalasan atas kesalahan yang telah dilakukannya. Dasar dari teori ini bersumber dari pemikiran Immanuel Kant, yang dikenal dengan sebutan retributivisme atau just desert theory yang menurutnya pidana yang diterima seseorang sudah merupakan bagian yang tidak terpisahkan dari kejahatan yang dilakukan. 
Sedangkan filsafat determinisme menjadi landasan ide sanksi tindakan bahwa hidup dan perilaku manusia ditentukan oleh faktor-faktor fisik, geografis, biologis, psikologis, sosiologis, ekonomis dan keagamaan yang ada ${ }^{11}$ dan sebagai landasan teori adalah teori relatif yang memandang bahwa pemidanaan bukan sebagai pembalasan atas kesalahan si pelaku, tetapi sebagai sarana mencapai tujuan yang bermanfaat untuk melindungi masyarakat menuju kesejahteraan masyarakat dan salahsatu pembagian dari sanksi tindakan adalah pidana kerja sosial.

Ada beberapa langkah atau strategi yang di gunakan dalam penelitian ini terkait sanksi kerja social yaitu: Pertama, Survey lapangan Hal pertama yang dilakukan adalah melakukan survey untuk menetukan tempat yang strategis dan mudah dikontrol terkait pelaksanaan penelitian. Kedua, Sosialisasi dengan melakuan audiens dengan kepolisian untuk meminta ijin setelah memasukkan ijin penelitian, selanjutnya memmasang spanduk dibeberapa titik serta membagikan stiker kepada pengendara lalu lintas hal tersebut dilakukan secara intens mengingat waktu penelitian yang singkat.
Ketiga, Berkerjasama dengan polisi untuk melakukan sweeping terhadap objek penelitian. Pada tahapan ini pihak kepolisisan melakukan sweeping dan terjaring beberapa pelnggar lalu lintas kemudian dan segera diamankan di kepolisisan lalu lintas kota parepare. Ada beberapa pelanggar lalu lintas Yang terjaring yaitu:

\footnotetext{
${ }^{11}$ M.Sholehuddin, Sistem Sanksi dalam Hukum Pidana, ide dasar Double Track System \& implementasinya, cetakan kedua, (Jakarta: RajaGrafindo Persada, 2004), hlm 33-36
} 
Tabel 1

\begin{tabular}{|c|c|c|c|}
\hline No. & Inisial & Usia & Pelanggaran \\
\hline 1 & SR & 17 & Tdak mempunyai SIM \\
2 & ED & 16 & Tidak memakai Helm \\
3 & FR & 17 & Tidak mempunyai SIM \\
4 & SD & 16 & Tidak mempunyai helm \\
5 & GF & 17 & Tidak mempunyai SIM \\
6 & HI & 18 & Tidak mempunyai helm \\
7 & SA & 18 & Tidak mempunyai SIM \\
8 & FE & 17 & Tidak mempunyai helm \\
9 & YU & 18 & Tidak mempunyai SIM \\
10 & DB & 18 & Tidak mempunyai SIM \\
& & & \\
\hline
\end{tabular}


Berdasarkan table 1 terlihat bahwa kebanyakan para pelanggar lalul lintas tidak memiliki SIM dan tidak memakai helm, dan kenagyakan dari kalangan pelajara sehingga hal terseburt menjadi sampel dalam penelitian ini. hal ini senada dengan penyataan Kasat lantas Parepare AKP Budi Susilo ${ }^{12}$ hal tersebut senada dengan pandangan Jarwo, kanit Lantas Kota Parepare ${ }^{13}$ bahwa kebanyakan pelanggar karena tidak memiliki SIM, STNK, tidak memakai helm dan melawan arah kebanyakan pelanggar adalah dari kalangan pelajar. Keempat, Melaksanakan sanksi kerja social/Bakti social yang terinsipirasi dari pidana kerja sosial, dimana melalui kerja sosial masyarakat mengetahui bahwa terpidana sudah dijatuhi hukuman sehingga memperkecil atau bahkan meniadakan kemungkinan balas dendam.

Pidana kerja sosial mempunyai beberapa keunggulan, diantaranya:

$>$ menisbihkan proses stigmatisasi

$>$ meniadakan efek negatif dari penjara yakni perampasan hak kemerdekaan orang

\footnotetext{
${ }^{12}$ Wawancara dengan AKP Budi Susilo, Kasat Lantas Kota Parepare, 10 September 2018

${ }^{13}$ Wawancara dengan Bapak Jarwo, Kanit Lantas Kota Parepare, 3 Mei 2018
}

dari persfektif ekonomi lebih $\operatorname{murah}^{14}$

yang terpenting dari keunggulankeunggulan tersebut bahwa yang menjadi patokan dalam pidana kerja sosial adalah pelakunya sehingga dikenai sanksi tindakan. Ada beberapa negara yang menerapkan pidana kerja sosial yaitu:

a). Portugal

Di Portugal pidana sosisal yang diterapkan yaitu berupa bekerja untuk kepentingan umum tanpa dibayar sebagai alternatif jika denda tidak dibayar. Perubahan terjadi pada KUHP 1983 ketika pidana kerja sosial ditempatkan sebagai pidana pokok, dimana pidana kerja sosial ini masih merupakan pidana bekerja tanpa dibayar.

b). Denmark

Di Denmark apabila seseorang dijatuhi pidana kerja sosial maka terpidana dimintai laporan dari badan yang mengawasi pidana bersyarat. Laporan yang berisi keadaan keluarga terpidana, sejarah pekerjaannya dan pendidikan terpidana. Laporan ini di gunakan untuk menentukan dapat tidaknya terpidana dikenakan pidana kerja sosial. Dalam prakteknya di Denmark sebenarnya sanksi pidana kerja sosial ditujukan terhadap pengganti sanksi pidana penjara jangka pendek dengan jangka

\footnotetext{
${ }^{14}$ Shinta Rukmi, prospek pidana kerja sosial di Indonesia, jurnal wacana Hukum, Vol VII no.1 april 2008
} 
waktu 15-18 bulan. Tetapi dalam kenyataannya pidana kerja sosial dikenakan terhadap pidana penjara yang dikenai pidana penjara antara 6-8 bulan.

c). Belanda

Di Belanda pidana kerja sosial hanya dapat dijatuhkan sebagai suatu pidana pokok. Pekerjaan yang dilakukan demi kepentingan pelayanan masyarakat umum. Pelaksanaan sanksi ini atas persetujuan terdakwa.

Dari beberapa gambaran konsep pidana kerja sosial tersebut dapat disimpulkan bahwa pidana kerja sosial merupakan alternatif untuk pidana jangka pendek dengan sasaran kegiatan untuk kepentingan umum atau pelayanan terhadap masyarakat tapi harus dengan persetujuan terdakwa atau terpidana dan dikaitkan dengan strategi yang penulis lakukan adalah mengganti Pidana Kerja social dengan saksi kerja social, hal ini didasarkan bahwa sanksi kerja social adalah proses non litigasi atau belum melalui proses persidangan sehingga istilah ini tepat digunakan berbeda dengan konsep pidana kerja social yang telah melalui proses litigasi atau peradilan. Terkait sanksi kerja social salahsatunya bentuk kegiatanya adalah pembagian sembako kepada masyarakat miskin serta memberikan pengarahan kepada pelanggar lalul lintas.
Terakhir, Melakukan pemasangan stiker untuk melakukan control, Pada tahapan ini peneliti memasangkan stiker dimotor pelanggar untk memudahkan identifikasi apakah masih melakakukan pelanggaran atau tidak.

Berdasarkan strategi diatas hal yang ingin dicapai diantaranya adalah culture Hukum yang lebih baik khususnya terkait lalu lintas, sebagaimana disebutkan LW. Friedman bahwa culture Hukum yaitu;

"Perilaku yang dipengaruhi oleh aturan, keputusan, perintah, atau Undang-Undang yang dikeluarkan oleh pejabat dengan wewenang hukum. Jika saya berprilaku secara khusus karena diperintahkan hukum atau karena tindakan pemerintah, atau amanat atau perintah dari pemerintah atau dari sistim hukum atau daru pejabat didalamnya, inilah perilaku hukum. Jika saya berkendaraan di sepanjang jalan dan melihat rambu batas kecepatan ( atau melihat polisi) dan memperlambat kendaraan, ini adalah perilaku hukum." 15

Terkait dengan strategi yang lain berdasarkan wawancara dengan mantan Kasat Lantas Kota Parepare AKP Ali ${ }^{16}$ surya, S.IK mengatakan strategi yang tepat juga sebagai langkah awal adalah mendirikan kampong sadar lalu lintas dan langkah awal yang dilakukan adalah melakukan survey awal tentang lokasi

\footnotetext{
${ }^{15}$ Achmad Ali, Menguak Teori hukum dan Teori Peradilan, cetakan ketiga (Jakarta:Prenada Media Group, 2010), hlm143

${ }^{16}$ Wawancaradengan AKP Ali surya ,S.IK, Mantan Kasat Lantas Kota Parepare,
} 
tempat pelaksanaannya dan hal yang harus diperhatikan adalah tempat masuk dan keluar warga harus melalui satu pintu sehingga mudah dikontrol, misalnya kawasan Perumahan, langkah berikutnya adalah melakukan komunikasi kepada kepala RT/RW dan masyarakat setempat untuk melakukan sosialisasi terkit dengan itu dengan muatan bahwa hal pertama yang diperhatikan adalah penggunaan Helem dan punishment terhadap pelanggar adalah melakukan kerja bakti dan menyetor sejumlah uang untuk kepentingan kompleks (bencana, hajatan, dll), selanjutnya bekerjasama dengan Satpam melalui ketua RT/RW untuk melakukan tugas mengadakan sweeping khususnya berkaitan dengan pemakaian helm. Pihak kepolisian dan pihak terkait harus menyiapkan beberapa helem di pos penjagaan.

Hal tersebut diatas menurut penulis sangat menarik untuk menumbukan kesadaran dalam berlalulintas tetapi harus diperkuat komunikasi serta sosialisasi dengan warga setempat serta juga harus memperhatikan prinsif cost and benefit artinya manfaat lebih besar daripada biaya yang dikeluarkan, dimana cost tidaka hanya dilihat secara materi tapi juga cost social.

Menurut Kasat Lantas Kota Parepare yang baru bapak AKP Budi
Susilo $^{17}$ mengatakan Bahwa strategi yang tepat untuk mengawali ini dimulai dari kawasan mahasiswa, misalnya didaerah UMPAR sebagai kawasan tertib lalu lintas sebagai percobaan setelah itu menerapkan dimasyarakat. Berdasarkan hal diatas penguatan yang dilakukan adalah sosialisasi sebagai langkah awal dan diperlukan daerah percontohan sebagai referensi untuk penerapan secara lebih komprehensif.

\section{Faktor-faktor yang mempengaruhi} penerapan sanksi kerja social di Kota Parepare

Untuk mengidentifikasi Faktor yang berpengaruh terhadap penerapan sanksi kerja social penulis menggunkan konsep LW. Friedman untuk menganalisi yaitu teori system Hukum bahwa pembangunan sistem hukum meliputi tiga komponen yakni substansi hukum (materi) atau (legal substance), struktur hukum (legal structure), dan budaya hukum (legal culture), yang mana ketiganya saling berkaitan.

Mengutip pandangan Djalal Abubakar seorang guru besar pada Program Pasca Sarjana Universitas Hasanuddin menjelaskan bahwa substansi hukum ini tidak hanya menyangkut kaidah

\footnotetext{
${ }^{17}$ Wawancara dengan AKP Budi Susilo, Kasat Lalu Lintas Kota Parepare, Parepare 10 September 2018
} 
tertulis (written law) yang lazim disebut peraturan perundang-undangan tetapi juga termasuk kaidah hukum yang tidak tertulis (unwritten law), termasuk dalam substansi hukum adalah keluaran sistem hukum itu sendiri, seperti jurisprudensi, keputusan dan sebagainya. ${ }^{18}$

Menurut L.M Friedman bahwa substansi hukum adalah aturan, norma dan pola prilaku nyata manusia yang berada dalam sistim itu, apakah tindakan yang dilakukan polisi sudah sesuai dengan substansi yang tentunya akan berkaitan dengan budaya hukum, dimana tindakan hukum adalah perilaku apa pun yang dilakukan oleh siapa pun yang memiliki otoritas yang bertindak dalam sistem hukum. ${ }^{19}$

Struktur hukum berkaitan dengan hal penegakan hukum (law enforcement), yakni bagaimana substansi hukum ditegakkan. Struktur hukum juga berkaitan dengan sistem peradilan yang berhubungan langsung dengan sumber daya manusia bidang hukum yang terdiri dari Hakim, Jaksa, Polisi, Pengacara, Pejabat lembaga pemasyarakatan, termasuk susunan kelembagaan dan yurisdiknya.

\footnotetext{
${ }^{18}$ Rusdin Tompo, ayo lawan korupsi (Makassar:LBH-P21,2005), hlm 44

${ }^{19}$ L.M Friedman, The legal system: A Social Science Perspective, Terjemahan, M.khozim, Sistem hukum: Perspektif sosial, cetakan IV (Bandung: Nusa Media, 2011), hlm80-81
}

Budaya hukum diibaratkan sebagai a working machine sistem hukum atau merupakan the element of social attitude and value. Jadi budaya hukum berkaitan dengan sikap budaya masyarakat pada umumnya, karena menyentuh keyakinan (belief), nilai (value), cita (idea), dan harapan (expectation) sehingga dapat dikatakan, kesadaran hukum masyarakat merupakan salah satu pencerminan budaya hukum mereka. Budaya hukum ini, menurut Roem Topatimasang dkk.meliputi persepsi, pemahaman, sikap penerimaan, praktik-praktik penerimaan, dan penafsiran terhadap isi dan tata laksana hukum. ${ }^{20}$

2.1 Faktor Pendukung penerapan sanksi kerja sosial

Faktor pendukung penerapan sanksi kerja social yaitu; Secara substansi yakni adanya konsep ultimum Remedium, Mengutip pandangan Djalal Abubakar seorang guru besar pada Program Pasca Sarjana Universitas Hasanuddin menjelaskan bahwa substansi hukum ini tidak hanya menyangkut kaidah tertulis (written law) yang lazim disebut peraturan perundang-undangan tetapi juga termasuk kaidah hukum yang tidak tertulis (unwritten law), termasuk dalam substansi hukum adalah keluaran sistem hukum itu

\footnotetext{
${ }^{20}$ Rusdin Tompo, loc. Cit.
} 
sendiri, seperti jurisprudensi, keputusan dan sebagainya. ${ }^{21}$

Menurut L.M Friedman bahwa substansi hukum adalah aturan, norma dan pola prilaku nyata manusia yang berada dalam sistim itu, olehnya itu penulis juga mengkaji substansi hukum, apakah tindakan yang dilakukan polisi sudah sesuai dengan substansi yang tentunya akan berkaitan dengan budaya hukum, dimana tindakan hukum adalah perilaku apa pun yang dilakukan oleh siapa pun yang memiliki otoritas yang bertindak dalam sistem hukum. ${ }^{22}$

Secara substansi Nilai-nilai pokok dari Hukum pidana bahwa eksistensi hukum pidana pada dasarnya meliputi keamanan dan ketertiban sebagai tujuan langsung $^{23}$ selain itu hakikat hukum pidana adalah utimum remedium atau langkah terakhir, hal ini berarti selama masih ada cara lain untuk menyelesaiakan persoalan tersebut, sebaiknya diselesaikan diluar ranah Hukum, seperti secara kekeluargaan dan sarana pidana adalah langkah terakhir. menurut sudikno mertokusuma, bahwa ultimum remedium

${ }^{21}$ Rusdin Tompo, ayo lawan korupsi (Makassar:LBH-P21,2005), hlm 44

${ }^{22}$ L.M Friedman, The legal system: A Social Science Perspective, Terjemahan, M.khozim, Sistem hukum: Perspektif sosial, cetakan IV (Bandung: Nusa Media, 2011), hlm80-81

${ }^{23}$ Siswanto sunarso, Filsafat Hukum Pidana, cetakan pertama (Jakarta:Rajawali pers,2015),hlm 167 bukan hanya istilah tetapi merupakan asas, olehnya itu sifatnya abstrak sehingga tidak dapat dituangkan didalam peraturan konkrit. $^{24}$

Menurut Prof Dr. wijono Prodjodikoro, istilah ultimum remedium mengatakan bahwa norma-norma atau kaidah-kaidah dalam bidang Hukum Tata Negara dan Hukum tata Usaha Negara harus pertama-tama ditanggapi dengan sanksi administrasi, begitu pula normanorma dalam bidang Hukum perdata pertama-tama harus ditanggapi dengan sanksi perdata, hanya apabila sanksi administrasi dan sanksi perdata belum mencukupi untuk mencapai tujuan meluruskan neraca kemasyarakatan, maka baru diadakan juga sanksi pidana sebagai pamungkas (terakhir) atau ultimum remedium. $^{25}$

Berdasarkan uraian terebut terlihat bahwa ultimum remedium dalam konteks pidana merupkan senjata pamungkas atau sarana terakhir dan dikaitkan dengan pelanggaran lalu lintas yang merupakan objek dalam tulisan ini bahwa dalam hal terjadinya pelanggaran lalul lintas khususnya dikota Parepare maka tawaran

24

http://www.hukumonline.com/klinik/detail/lt53b7b e52bcf59/arti-ultimum-remedium, diakses 11 September 2018

${ }^{25}$ Ibid., 
penulis sebagaimana pengejawantahan konsep ultimum remedium maka pelanggar lalu lintas diberi saksi kerja social tanpa melalui ranah Hukum.

Hal tersebut diatas sejalan dengan pernyatan Ibrahim $^{26}$, warga jalan Andi Makassau Timur Parepare bahwa mereka sepakat dengan penyelesaian pelanggaran lalu lintas di luar pengadilan atau jalur Hukum dengan alasan karena prosedur penyelesaian Hukum yang ruwet dan kerja social bisa meningkatkan persatuan dan persaudaraan, hal tersebut sejalan dengan pandangan Dullah $^{27}$ warga Jalan Andi Makassau RT 1 yang juga mendukung cara tersebut, pun demikian $\operatorname{Raup}^{28}$ yang berprofesi sebagai tukang ojek warga jalan lenungan kota Parepare juga mendukung Hal tersebut, menurut langke ${ }^{29}$ warga jalan ambo mati kota parepare Dari beberapa pernyataan responden terlihat bahwa masyarakat mendukung konsep kerja social sebagai alternative penalisasi dan hal tersebut sejalan dengan kosep Ultimum remedium.

Faktor pendukung selanjutnya adalah adanya kewenangan Diskresi yang

\footnotetext{
26 Wawancara dengan Ibrahim, Warga Kota Parepare 10 September 2018

${ }^{27}$ Wawancara dengan Dullah, Warga Kota Parepare 10 September 2018

${ }^{28}$ Wawancara dengan Rauf, Warga Kota Parepare 10 September 2018

${ }^{29}$ Wawancara dengan Langkeng, Warga Kota Parepare 10 September 2018
}

dimiliki Pihak kepolisian sehingga penerapan Sanksi kerja social bisa lebih mudah dengan adanya kewenangan diskresi tetapi harus tetap ditopang aturan atau regulasi tertulis. Diskresi dalam Black law dictionary berasal dari bahasa Belanda "Discretion yang berarti kebijaksanaan dalam hal memeutuskan sesuatu tindakan berdasarkan ketentuan-ketentuan peraturan, Undang-undang atau Hukum yang berlaku tetapi atas dasar kebijaksanaan, pertimbangan atau keadilan. Thomas J mendefenisikan

"Discretion is power authority conferred by law to action on the basic of judgement of conscience, and its use is more than idea of morals than law". yang dapat diartikan sebagai suatu kekuasaan atau wewenang yang dilakukan berdasarkan hukum atas pertimbangan dan keyakinan serta lebih menekankan pertimbangan-pertimbangan moral dari pada pertimbangan hukum. ${ }^{30}$

Jadi sekalipun belum ada aturan terkait dengan sanksi kerja social, dengan adanya kewenangan dikresi kepolisian maka sanksi kerja social dapat diterapkan terhadap pelanggaran lalu lintas dikota Parepare, dimana sesuai dengan pernyataan diatas langkah yang ditempuh yakni bersama-sama dengan polisi terjun ke masyarakat untuk melaukan kerja social

\footnotetext{
https://ferli1982.wordpress.com/2013/01/15/diskres i-kepolisian-2/, diakses tanggal 11 september 2018
} 
dan bakti social (membagi sembako) dan hal tersebut sangan mendukung konsep Polisi Masyarakat.

Hal senada diungkapakan Kasat Lantas Kota Parepare AKP Budi Susilo ${ }^{31}$ bahwa penerapan sanksi kerja social itu mudah diterapkan mengingat adanya kewenangan diskresi yang dimiliki oleh pihak kepolisian. Olehnya itu sebagai kesimpulan bahwa penerapan sanksi kerja social akan lebih mudah diterapkan dengan adanya kewenangan diskresi yang dimiliki oleh pihak kepolisian dan tetap haru ditopang dengan regulasi atau aturan tertulis.

Terkait dengan kewenangan diskresi ada beberapa hal yang harus diperhatikan yaitu $^{32}$

- Tindakan yang harus "benar-banar dilakukan "noodzakelijk, notwending" atau azas keperluan.

- Tindakan yang diambil benar-benar untuk kepentingan tugas kepolisian “Zakelijk, sachlich).

- Tindakan yang paling tepat untuk mencapai sasaran yaitu hilangnya

\footnotetext{
${ }^{31}$ Wawancara dengan AKP Budi Susilo, Kasat lantas Kota Parepare, 10 September 2018 32
}

https://nixwanto.wordpress.com/2008/12/01/diskres i-polisi-dan-permasalahannya/, diakses 11 September 2018 suatu gangguan atau tidak terjadinya sesuatu yang tidak dikhawatirkan. Dalam hal ini yang dipakai sebagai ukuran yaitu tercapainya tujuan (Zweckmassig, doelmatiq).

Azas keseimbangan (evenredoig) dalam mengambil tindakan, harus senantiasa dijaga keseimbangan antara sifat (keras lunaknya) tindakan atau sasaran yang dipergunakan dengan besar kecilnya suatu gangguan atau berat ringannya suatu obyek yang harus ditindak.

Dalam pelaksanaan diskresi azas tersebut harus menjadi pertimbangan pihak kepolisian dalam mengambil kebijakan dan menurut penulis hal yang juga harus diperhatikan hendaknya dalam pengambilan kebijakan diskresi adalah memperhatikan prinsif cost and benefit seperti halnya dalam kriminalisasi sebuah kasus, ketika dikaitkan dengan kewenangan diskresi maka pilihan kebijakan diskresi mestinya harus lebih banyak manfaatnya daripada sebelumnya.

2.2 Faktor penghambat penerapan sanksi kerja sosial

Faktor penghambat penerapan saksi kerja social yaitu; pertama, Aturan atau regulasi/substansi. Menurut L.M Friedman 
bahwa substansi hukum adalah aturan, norma dan pola prilaku nyata manusia yang berada dalam sistim itu, apakah tindakan yang dilakukan polisi sudah sesuai dengan substansi. ${ }^{33}$ Belum adanya regulasi menjadi penghambat pelaksanaan sanksi kerja social, meskipun adanya kewenangan diskresi. Pelanggaran lalu lintas adalah ranah pidana dimana berlaku asas Hukum pidana yakni asas legalitas "nullum delictum, nulla poena sine pravevia legi poenalli". Asas legalitas ini memiliki 4 makna atau hal menurut Boot ${ }^{34}$, yang pertama, prinsif nullum crimen, noella poena sine lege praevia artinya tidak ada perbuatan pidana, tidak ada pidana tanpa Undang-undang sebelumnya. Kedua, nulla poena sine lege scripta artinya tidak ada pidana tanpa Undangundang tertulis. Ketiga, nulla poena sine lege certa artinya tidak ada pidana tanpa aturan undang-undang yang jelas, dan keempat, noela poena sine lege sticta artinya tidak ada pidana tanpa undangundang yang ketat.

Berdasarkan hal tersebut pengaturan tentang lalu lintas khususnya terkait penerapan sanksi kerja social terhadap pelanggaran lalu lintas yang juga merupakan ranah pidana sudah semestinya

\footnotetext{
${ }^{33}$ L.M Friedman, The legal system: A Social Science Perspective, Terjemahan, M.khozim, Sistem hukum: Perspektif sosial, cetakan IV (Bandung: Nusa Media, 2011), hlm 80-81

${ }^{34}$ Hiariej, op.cit, hlm 59-61
}

diatur dalam aturan tertulis sehingga lebih memiliki kekuatan Hukum. Kedua, kurangnya Sosialisasi adalah factor penghambat penerapan sanksi kerja social, sosialisasi ini tidak hanya kepada masyarakat, pemerintah, pihak kepolisian bahkan semua pihak terkait dan dilakukan secara intens sehingga tercipta efektifitas sanksi kerja social ini khususnya para pelanggar yang terbanyak yakni dari pelajar menurut Kasat Lantas Kota Parepare AKP Budi Susilo ${ }^{35}$ sosialisasi dapat dilakukan secara formal maupun informal diantaranya yang efektif menurut Kasat Lantas Kota Parepare adalah mendekati masyarakat melaui pendekatanpendekatan ideology atau potrologis dengan nongkrong bersama pemuda atau dialog dengan tokoh-tokoh masyarakat.

Kominikasi sangatlah penting dalam mempengaruhi perilaku Hukum. Menurtu Lawrence M. Friedman menguraikan tentang bagaimana mempengaruhi perilaku hukum, yaitu yang pertama komunikasi hukum (communication of the law), bagaimanakah aturan ini dikomunikasikan, ada aturan yang sebenarnya menjadi pengetahuan umum. Sebagian besar aturan dan tentunya semua aturan yang teknis, aturan administratif yang diperinci harus

\footnotetext{
${ }^{35}$ Wawancara dengan AKP Budi Susilo, Kasat Lantas Kota Parepare, 10 September 2018
} 
disampaikan secara khusus kepada audiensnya, yang kedua adalah pengetahuan hukum (knowledge of law) dimana pengetahuan hukum sebagai faktor esensial perilaku hukum, seberapa banyak kemampuan seseorang memahami tentang sebuah aturan hukum yang tentunya akan berpengaruh terhadap perilaku atau budaya hukum. ${ }^{36}$

Komunikasi memang vital artinya bagi dampak, tetapi komunikasi hanya merupakan prasyarat; komunikasi tidak bisa menjelaskan bagaimana dan mengapa orang-orang yang menerima pesan itu bertindak. Ada dua jenis komunikasi organisasi yakni komunikasi vertikal baik komunikasi dari atas ke bawah atau dari bawah ke atas dan komunikasi horisontal yakni komunikasi mendatar antar personil. ${ }^{37}$ dan komunikasi akan tersampaikan dengan baik manakala komunikatornya memenuhi syarat seperti, memiki kredibilitas (terpercaya), objektivitas (melihat seluruh sisi masalah) dan keahlian ( pakar dan memenuhi kualifikasi). ${ }^{38}$ Dan apabila sebuah kekuasaan menghendaki suatu bentuk tindakan komunikatif, maka penguasa

\footnotetext{
${ }^{36}$ Achmad Ali, Menguak Teori ... op. Cit., hlm143165

${ }^{37}$ Suwarni, Reformasi Ke-Polisian,op,cit hlm 38

${ }^{38}$ Alo Liliweri, Dasar-dasar komunikasi antar Budaya, cetakan IV (Yogyakarta:Pustaka Pelajar, 2009), hlm 91
}

harus mengadopsi ideologi terbuka, dengan demikian kekuasaan yang terbangun adalah kekuasaan yang berpondasi relasi yang baik antara anggotanya menjadi kehidupan yang berkualitas, dimana kekuasaan adalah milik bersama dan bukan milik induvidu. ${ }^{39}$ Jadi agar efektifitas penerapan saknsi kerja social terpenuhi maka komunikasi harus lebih intens dilakukan baik secara formal maupun informal.

Ketiga, berkaita dengan Culture Hukum, Budaya hukum diibaratkan sebagai a working machine sistem hukum atau merupakan the element of social attitude and value. Jadi budaya hukum berkaitan dengan sikap budaya masyarakat pada umumnya. Menurut LW Friedman Budaya Hukum ada 2 yaitu; Budaya Hukum Internal yakni budaya Hukum aparat penegak Hukum dan budaya Hukum Eksternal yakni budaya Hukum anggota masyarakat.

Secara eksternal khususnya dalam konteks kota Parepare menurut kasat Lantas Kota Parepare AKP Budi Susilo ${ }^{40}$ hal yang kurang adalah pendewasaan masyarakat, sebagai contoh secara kasat mata mereka melakukukan pelanggaran, tetapi setelah ditegur mereka masih

\footnotetext{
${ }^{39}$ Rieke Diah Pitaloka, Kekerasan negara menular ke Masyarakat, cetakan pertama (Yogyakarta:Galangpress, 2004), hlm 183-184 ${ }^{40}$ Wawancara dengan AKP Budi Susilo, Kasat Lantas Kota Parepare, 10 September 2018
} 
mengeluarkan argumentasi sebagai alasan pembenar. Selain itu berkaitan dengan budaya yang dimiliki oleh masyarkat setempat seperti terlihat dari kenayakan pelanggar adalah pelajar kemudian ditahan dan orang tuanya marah-marah.

Budaya lokal untuk masyarkat Sulawesi-selatan dikenal budaya Siri' Na Pacce. Secara lafdzhiyah Siri' berarti : Rasa Malu (harga diri), sedangkan Pacce atau dalam bahasa Bugis disebut Pesse yang berarti : Pedih/Pedas (Keras, Kokoh pendirian). Jadi Pacce berarti semacam kecerdasan emosional untuk turut merasakan kepedihan atau kesusahan individu lain dalam komunitas (solidaritas dan empati).

Kata Siri', dalam bahasa Makassar atau Bugis, bermakna "malu”. Sedangkan Pacce (Bugis: Pesse) dapat berarti "tidak tega" atau "kasihan" atau "iba". falsafah dan ideologi Siri' na pacce/pesse, maka keterikatan dan kesetiakawanan di antara mereka menjadi kuat, baik sesama suku maupun dengan suku yang lain. Beradasarkan nilai-nilai yang terkandung budaya siri' na pacce terbagi atas 3 yaitu:

- Nilai Filosofis.

Nilai Filosofis siri' na pacce adalah gambaran dari pandangan hidup orang-orang Bugis dan Makassar mengenai berbagai persoalan kehidupan yang meliputi watak orang Bugis Makassar yang reaktif, militan, optimis, konsisten, loyal, pemberani dan konstruktif.

\section{- Nilai Etis}

Pada nilai-nilai etis siri' na pacce terdapat nilai-nilai yang meliputi: teguh pendirian, setia, tahu diri, jujur, bijak, rendah hati, sopan, cinta dan empati.

- Nilai Estetis

Nilai estetis dari siri' na pacce meliputi nilai estetis dalam non insani yang terdiri atas benda alam tak bernyawa, benda alam nabati, dan benda alam hewani.

Budaya siri' na pacce adalah sesuatu yang sangat dibutuhkan oleh bangsa ini, untuk menjadi sebuah bangsa yang besar. Untuk itu diperlukan sosoksosok muda yang memiliki jiwa dan karakter yang mapan karena pemuda adalah calon pemimpin dan pemiliki bangsa ini. Mereka harus memiliki siri' na pacce dalam diri mereka, dengan adanya budaya siri' na pacce anak pemuda bangsa ini akan menjadi lebih peka terhadap segala macam persoalan yang sedang melanda bangsa ini. 
Seorang pemimpin yang memiliki budaya siri' na pacce dalam dirinya akan menjadi seorang pemimpin yang memiliki keberanian serta ketegasan, namun tetap bijaksana dalam memimpin. Seorang pemimpin yang memegang prinsip ini akan membawa bangsa ini menuju kearah yang lebih baik, karena mereka memiliki rasa peka terhadap lingkungan, mampu mendengarkan aspirasi-aspirasi orangorang yang mereka pimpin karena itu sejalan dengan konsep negara kita yaitu Demokrasi. $^{41}$ Budaya melekat dalam karakter masyarakat bugis dan harus menjadi bahan pertimbangan dalam penerapan sanksi kerja social sehingga tidak terjadi resistensi.

Menurut LW Friedman selain budaya eksternal diatas juga ada budaya internal yakni budaya aparat penegak Hukum yang secara ideologis juga harus di isi dengan nilai-nilai yang baik sehingga terlahir aturan serta perilaku yang baik pula diantarnya nilai-nilai siri na pace tadi sebagai budaya lokal dan juga budaya yang penulis tawarkan seperti nilai-nilai profetik yaitu:

Konsep profetik dilontarkan salahsatunya oleh Kuntowijoyo bahwa Ilmu Sosial Profetik tidak hanya menolak 41

http://Fairuzelsaid.wordpress.com/2011/06/27/Sir i' Na Pacce/

"Siri' Na Pacce," Akses 18 november 2013 klaim bebas nilai dalam positivisme tapi lebih jauh juga mengharuskan ilmu sosial untuk secara sadar memiliki pijakan nilai sebagai tujuannya. Ilmu Sosial Profetik tidak hanya berhenti pada usaha menjelaskan dan memahami realitas apa adanya tapi lebih dari itu mentransformasikannya menuju cita-cita yang diidamkan masyarakatnya. Ilmu Sosial Profetik kemudian merumuskan tiga nilai penting sebagai pijakan yang sekaligus menjadi unsur-unsur yang akan membentuk karakter paradigmatiknya, yaitu humanisasi, liberasi dan transendensi, dimana :

Pertama, Transendensi, hal ini berperan penting dalam memberikan makna yang akan mengarahkan tujuan hidup manusia. Islam dapat membawakan kepada dunia yang sekarat, bukan karena kurang alat atau teknik, akan tetapi karena kekurangan maksud, arti dari masyarakat yang ingin merealisir rencana Tuhan. Nilai-nilai transendental ketuhanan inilah yang akan membimbing manusia menuju nilai-nilai luhur kemanusiaan.

Transendensi adalah dasar dari humanisasi dan liberasi. Transendensi memberi arah kemana dan untuk tujuan apa humanisasi dan liberasi itu dilakukan. Transendensi dalam Ilmu Sosial Profetik di samping berfungsi sebagai dasar nilai bagi 
praksis humanisasi dan liberasi, juga berfungsi sebagai kritik. Dengan kritik transendensi, kemajuan teknik dapat diarahkan untuk mengabdi pada perkembangan manusia dan kemanusiaan, bukan pada kehancurannya. Melalui kritik transendensi, masyarakat akan dibebaskan dari kesadaran materialistik-di mana posisi ekonomi seseorang menentukan kesadarannya-menuju kesadaran transendental. Transendensi akan menjadi tolok ukur kemajuan dan kemunduran manusia.

Kedua, Humanisasi berarti memanusiakan manusia, menghilangkan "kebendaan", ketergantungan, kekerasan dan kebencian dari manusia. Humanisasi sesuai dengan semangat liberalisme Barat. Hanya saja perlu segera ditambahkan, jika peradaban Barat lahir dan bertumpu pada humanisme antroposentris, konsep humanisme Kuntowijoyo berakar pada humanisme teosentris. Karenanya, humanisasi tidak dapat dipahami secara utuh tanpa memahami konsep transendensi yang menjadi dasarny, dan terakhir, Liberasi dalam Ilmu Sosial Profetik sesuai dengan prinsip sosialisme (marxisme, komunisme, teori ketergantungan, teologi pembebasan). Hanya saja Ilmu Sosial Profetik tidak hendak menjadikan liberasinya sebagai ideologi sebagaimana komunisme. Liberasi Ilmu Sosial Profetik adalah dalam konteks ilmu, ilmu yang didasari nilai-nilai luhur transendental. Jika nilai-nilai liberatif dalam teologi pembebasan dipahami dalam konteks ajaran teologis, maka nilai-nilai liberatif dalam Ilmu Sosial Profetik dipahami dan didudukkan dalam konteks ilmu sosial yang memiliki tanggung jawab profetik untuk membebaskan manusia dari kekejaman kemiskinan, pemerasan kelimpahan, dominasi struktur yang menindas dan hegemoni kesadaran palsu. $^{42}$

Nilai-nilai tersebut bisa menjadi alternative sehingga tercipata aturan yang responsive dan juga melahirkan sikap atau budaya Hukum yang sesuia dengan nilai yang dianut oleh sesorang.

\section{Dampak penerapan sanksi kerja social terhadap pelanggar lalu lintas dikota Parepare}

Ada beberapa dampak dari penerapan sanksi kerja social terhadap pelanggaran lalu lintas didasarkan pada pandangan LW Friedman tentang system Hukum didasarkan pada tiga Hal yaitu;

\footnotetext{
${ }^{42}$ Jawahir Thantowi. Paradigma Profetik dalam pengajaran dan penelitian hukum. UNISIA, Vol.XXXIV No. 76 Januari 2012
} 
pertama, Substansi adalah norma, aturan atau Undang-undang yang merupakan hal yang ingin dicapai dari penerapan kerja social sehingga pengaturan sanksi kerja social bisa lebih jelas dengan dibuatkannya peraturan bukan lagi hanya mengandlkan kewenangan diskresi yang sifat terkadang subjektif. Selain itu hal yang penting juga adalah penerapan atau tindak lanjut dari konsep Polisi Masyarakat (Polmas).

Istilah polisi masyarakat dalam bahasa Inggris disebut community-based policing (pemolisian berbasis masyarakat), community-oriented policing (pemolisian berorientasi masyarakat), neighborhoodoriented policing (pemolisian berorientasi pemukiman), dan community policing (pemolisian masyarakat). Ada banyak definisi yang muncul seperti dari polisi ontario Canada (ontarior provincial police) merumuskan:

"Community plicing is the delivery of policing service, resulting from a community and police parthnership that identifies and resolves issue in order to maintain social order"'

"Polmas adalah pemberian jasa pemolisian yang berasal dari kemitraan masyarakat dan polisi yang mengidentifikasi dan memecahkan berbagai isu dalam rangka mempertahankan tertib sosial"

Konsep polmas merujuk pada pengertian pemolisian berorientasi pada komunitas, beririentasi pada masalah, dan masih banyak lagi istilah-istilah yang lain yang akan berdamapak pada penerapan model polmas, tetapi secara umum polmas memiliki prinsip-prinsip fundamental yang sama yaitu:

- Tujuan : menurunkan rasa takut dikalangan warga, meningkatkan kepuasan warga terhadap polisi dan pengembangan teknik-teknik untuk mengatasi masalah-masalah masyarakat.

- Prinsip: membangun komunitas (Community building), kepercayaan (Trust), dan kerjasama.

Konsep polmas juga disebutkan Lieghton bahwa:

- Sasaran untuk menjamin kedamaian, ketertiban, keberadaban, untuk menyediakan jasa-jasa yang terkait dengan komunitas serta utuk menumbuhkan rasa aman di masyarakat.

- Agen-agen polmas adalah organisasi-organisasi yang berorientasi pelayanan dan memandang publik sebagai klien dari polisi yang menggunakan jasa mereka.

- Suatu strategi kunci polamas adalah menganut pendekatan pro-aktif 
terhadap kejahatan dan masalah ketertiban.

- Komposisi pelayanan polisi bergeser kearah refleksi yang lebih baik atas komposisi demografi dan sosial dari masyarakat yang mereka layani.

- Kriteria sukses dari efektivitas pelayanan polisi atau kinerja polisi ditentukan oleh publik yang memanfaatkan jasa mereka.

Yang terutama, polmas menekankan kemitraan penuh antara komunitas dengan polisi didalam mengidentifikasi dan mengatasi kejahatan setempat serta masalah ketertiban, polmas memepercayai bahwa kejahatan dan masalah ketidaktertiban adalah milik bersama komunitas (sebagai klien) dengan polisi (sebagai penyedia jasa pelayanan), polmas juga meyakini bahwa anggotaanggota komunitas perlu berpartisipasi dalam merumuskan kebijakan publik yang berdasarkan hubungan interaktif dan koperatif.

Lebih jauh konsep polamas dapat dipahami dengan mengidentifikasi karakteristik utamanya, misalnya Goldstein mengaitkan pemolisian dengan berorientasi masalah, dan mengaitkan bahwa polisi paling mungkin meningkatkan produktivitas dengan komunitasnya jika:
- Menugaskan anggota polisi ke wilayah secara cukup lama sehingga memungkinkan mereka untuk mengidentifikasi masalahmasalah yang menjadi perhatian masyarakat.

- Mengembangkan kapasitas anggota maupun institusi kepolisian dalam menganalisa masalah-masalah masyarakat.

- Mempelajari apakah keterlibatan yang lebih besar dari masyarakat mempunyai potensi untuk secara signifikan mengatasi suatu masalah.

- Dalam situasi seperti itu, bekerja dengan segmen tertentu di masyarakat yang berada pada posisi untuk membantu mengurangi atau mengatasi masalah. ${ }^{43}$

Dalam pelaksanaannya konsep polmas tergantung model apa yang akan diterapkan misalnya, di Jepang dengan sistem Koban, yaitu kegiatan polisi berorientasi masyarakat, polisi jepang terdiri dari badan kepolisian nasional (national police agency=NPA) sebagai koordinator dan badan penentu kebijakan dan 47 daerah kepolisian sebagai orbganisasi penegak hukum, dimana setiap markas besar daerah kepolisian memiliki 10-100 kantor polisi cabang dan sistem Koban dioperasiakn di daerah kantor

\footnotetext{
${ }^{43}$ Sutanto, Polmas ...po.cit., hlm 10-11
} 
cabang tersebut, karena jumlah petugas polisi yang kecil maka kerjasama antara polisi dan masyarakat adalah syarat mutlak dalam sistem ini.

Unit dasar dari sistem koban ini adalah koban (pos polisi) yang letaknya diperkotaan dan Chuzaisho (pos rumah) yang letaknya ada di pedesaan, sistem kerjanya untuk polisi koban secara normal bekerja dalam 3 giliran perhari, dimana setiap giliran terdiri atas 3 atau lebih petugas polisi yang tergabung dalam satu kelompok, tapi di Chuzaisho hanya ada satu polisi yang ditempatkan disana dan mendapat fasilitas tempat tinggal dengan keluarganya, meskipun waktu kerjanya terbatas tapi pada saat terjadi kecelakaan ia harus menangani kecelakaan tersebut walau pada tengah malam sekalipun.

Tugas utama mereka adalah siap melaksanakan tugas dengan fasilitas kepolisian yang diberikan, menangani berbagai laporan, permintaan dan keluhan penduduk, mengambil inisiatif bereaksi bila terjadi kejahatan/kecelakaan, melakukan patroli dan melakukan kunjungan reguler ke rumah penduduk di daerah kewenangannya, disamping itu terdapat polisi Binmas yang digerakkan dalam mobil patroli, tugas utama meraka mengambil inisiatif pada kecelakaan dan melakukan patroli. ${ }^{44}$

Berdasarkan hal tersebut diatas maka maka penulis menggunakan konsep polisi rakyat (civil oriented police) sebagaimana diterapkan di Jepang dengan sistem koban, dimana model polisi yang ingin ditampilkan disini adalah"polisi rakyat" dimana polisi dituntut melakukan tugas berdasarkan kreativitas dan empati yaitu empati pada rakyat yang dilayani, sifat pekerjaannya yang betul-betul berada ditengah-tengah dan bersama-sama rakyat, dimana mulai dari pakaian seragamnya yang tidak seragam lagi, artinya memakai baju orang biasa, sampai pada jenis dan jumlah pekerjaannya yang tidak dihitung lagi itu, membantu dan melayani masyarakat berdasarkan kebutuhan masyarakat sendiri dan bukan kebutuhan masyarakat sebagaimana dilihat dan ditafsirkan oleh pemerintah, sehingga menjadikan mereka sebagai teman rakyat dalam arti yang sebenarnya ${ }^{45}$. Dengan adanya kegiatan sanksi kerja social ini diharapkan tujuan dari Polisi masyrakat dapat terpenuhi, sehingga polisi dan masyarakat bisa berbaur dan masyarakat itdak lagi apatis tekait dengan persoalan-

\footnotetext{
${ }^{44}$ Kunarto dan hariadi kuswaryono, Polisi dan masyarakat, cetakan pertama (Jakarta: Cipta manunggal, 1998), hlm 39-41

${ }^{45}$ Satjipto Rahardjo, Polisi sipil dalam perubahan sosial di Indonesia, cetakan pertama

(Jakarta:Kompas media nusantara, 2002) hlm 73-74
} 
persolan Hukum khususnya yang melibatkan pihak kepolisian.

\section{KESIMPULAN}

Adapun kesimpulan dari hasil penelitian ini adalah sebagai berikut; strategi atau langkah yang dilakukan yaitu; Survey lapangan, Sosialisasi, Berkerjasama dengan polisi untuk melakukan sweeping terhadap objek penelitian, Melaksanakan sanksi kerja social/Bakti social, Melakukan pemasangan stiker untuk melakukan control dan perlu daerah percontohan sebagai daerah percontohan seperti kampong sadar Lalu lintas, kampong tertib lalu lintas.

$$
\text { Adapun Faktor yang }
$$

mempengaruhi penerapan sanksi kerja social yaitu; pertama, Faktor Pendukung yaitu: Secara substansi yakni adanya konsep ultimum Remediu atau sarana pidana sebagai langkah terakhir dan adanya kewenagan Diskresi suatu kekuasaan atau wewenang yang dilakukan berdasarkan hukum atas pertimbangan dan keyakinan serta lebih menekankan pertimbangan-pertimbangan moral dari pada pertimbangan hukum. Factor selanjutnya yaitu factor penghambat diantranya; Aturan atau regulasi/substansi secara tertulis yang belum ada dan Sosialisasi yang kurang, serta Culture Hukum atau sikap baik masyarakat maupun polisi yang masih rendah terkait masalah Hukum. Dan dampak penerapan sanksi kerja social adalah akan terciptanya aturan atau Undang-undang yang khusus mengatur masalah sanksi kerja social. Hal selanjutnya adalah terciptanya Konsep Polisi Masyarakat (Polmas).

\section{Daftar Pustaka}

\section{Buku}

Achmad Ali, Menguak Teori hukum dan Teori Peradilan, Jakarta:Prenada Media Group, 2010.

Diah Pitaloka, Rieke, Kekerasan negara menular ke Masyarakat, Yogyakarta:Galangpress, 2004.

Eddy O.S. Hiariej, Prinsif-prinsif Hukum Pidana, Yogyakarta:Cahaya Atma Pustaka, 2015.

Kunarto dan Hariadi kuswaryono. Polisi dan masyarakat, Jakarta: Cipta manunggal, 1998.

Kusumohamidjojo, Budiono. Filsafat Kebudayaan proses realisasi manusia, Yogyakata:Jalasutra, 2010.

Liliweri, Alo.Dasar-dasar komunikasi antar Budaya, Yogyakarta:Pustaka Pelajar, 2009.

L.M Friedman, The legal system: A Social Science Perspective, Terjemahan, M.khozim, Sistem hukum: Perspektif sosial, Bandung: Nusa Media, 2011.

Moeljanto, Asas-Asas Hukum Pidana, Jakarta:Pt. Rineka Cipta, 2008.

Prasetyo,Teguh dan Abdul Halim Barkatullah. Politik Hukum Pidana, Yogyakarta: Pustaka Peljar, 2012.

Rahardjo, Satjipto. Polisi sipil dalam perubahan sosial di Indonesia, Jakarta:Kompas media nusantara, 2002.

Sadjijono. Hukum kepolisian, Yogyakarta: Laksbang Pressindo, 2006.

Sholehuddin, M, Sistem Sanksi dalam Hukum Pidana,ide dasar double track system \& implementasinya, 
Jakarta:PT RajaGrafindo Persada, 2004.

Sutanto, dkk., Polmas falsafah baru Pemolisian, cetakan kedua (Jakarta:Pensil-324, 2008.

Suwarni, Reformasi Ke-Polisian, Yogyakarta:UII Press, 2010.

Tompo, Rusdin, ayo lawan korupsi, Makassar:LBH-P21,2005.

Widodo, sistem pemidanaan dalam cyber crime, Mediatama, 2009.

\section{Jurnal}

Rukmi, Shinta. prospek pidana kerja sosial di Indonesia, jurnal wacana Hukum, Vol VII no.1 april 2008.

Thantowi, Jawahir . Paradigma Profetik dalam pengajaran dan penelitian hukum. UNISIA, Vol.XXXIV No. 76 Januari 2012

\section{Naskah Internet}

http://news.rakyatku.com/read/6981/2016/ 05/30/323- , diakses tanggal 9 Mei 2017

http://lintasterkini.com/03/11/2016/databps-warga-miskin-kota-pareparecapai-8-400-orang.html, diakses tanggal 18 Juni 2017

http://id.wikipedia.org/wiki/budaya, diakses 22 februari 2017

http://nurulantropologi.blogspot.com/2011/ 03/budaya-hukum-seni-hukum-dansistem.html, diakses tanggal 17 juni 2014-06-19

https://ferli1982.wordpress.com/2013/01/1

5/diskresi-kepolisian-2/, diakses tanggal 11 september 2018

https://nixwanto.wordpress.com/2008/12/0

1/diskresi-polisi-dan-

permasalahannya/, diakses 11

September 2018

http://Fairuzelsaid.wordpress.com/2011/06 /27/Siri' Na Pacce/

"Siri' Na Pacce," Akses 18 november 2013

\section{Hasil Wawancara Penelitian}

Wawancaradengan AKP Ali surya ,S.IK, Mantan Kasat Lantas Kota Parepare, 4 April 2018

Wawancara dengan Bapak Jarwo, Kanit Lantas Kota Parepare, 3 Mei 2018 Wawancara dengan AKP Budi Susilo, Kasat Lantas Kota Parepare, 10 September 2018

Wawancara dengan Dullah, Warga Kota Parepare 10 September 2018

Wawancara dengan Ibrahim, Warga Kota Parepare 10 September 2018

Wawancara dengan Langkeng, Warga Kota Parepare 10 September 2018

Wawancara dengan Rauf, Warga Kota Parepare 10 September 2018 